\title{
Changes in Antioxidative, Oxidoreductive and Detoxification Enzymes during Development of Aphids and Temperature Increase
}

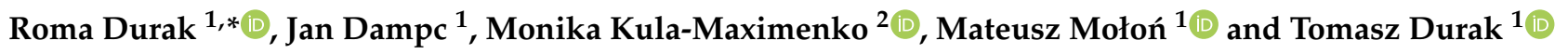 \\ 1 Institute of Biology and Biotechnology, University of Rzeszów, Pigonia 1, 35-310 Rzeszów, Poland; \\ jdampc@ur.edu.pl (J.D.); mateuszmolon@univ.rzeszow.pl (M.M.); tdurak@univ.rzeszow.pl (T.D.) \\ 2 The Franciszek Górski Institute of Plant Physiology, Polish Academy of Sciences, Niezapominajek 21, \\ 30-239 Kraków, Poland; m.kula@ifr-pan.edu.pl \\ * Correspondence: rdurak@univ.rzeszow.pl
}

Citation: Durak, R.; Dampc, J.; Kula-Maximenko, M.; Mołoń, M.; Durak, T. Changes in Antioxidative, Oxidoreductive and Detoxification Enzymes during Development of Aphids and Temperature Increase. Antioxidants 2021, 10, 1181. https:// doi.org/10.3390/antiox10081181

Academic Editor: Hiroko Tabunoki

Received: 16 June 2021

Accepted: 21 July 2021

Published: 25 July 2021

Publisher's Note: MDPI stays neutral with regard to jurisdictional claims in published maps and institutional affiliations.

Copyright: (c) 2021 by the authors. Licensee MDPI, Basel, Switzerland. This article is an open access article distributed under the terms and conditions of the Creative Commons Attribution (CC BY) license (https:/ / creativecommons.org/licenses/by/ $4.0 /)$.

\begin{abstract}
Temperature, being the main factor that has an influence on insects, causes changes in their development, reproduction, winter survival, life cycles, migration timing, and population dynamics. The effects of stress caused by a temperature increase on insects may depend on many factors, such as the frequency, amplitude, duration of the stress, sex, or the developmental stage of the insect. The aim of the study was to determine the differences in the enzymatic activity of nymphs and adult aphids Aphis pomi, Macrosiphum rosae and Cinara cupressi, and changes in their response to a temperature increase from 20 to $28^{\circ} \mathrm{C}$. The activity of enzymatic markers (superoxide dismutase (SOD), catalase (CAT), glutathione S-transferase (GST), $\beta$-glucosidase, polyphenol oxidase (PPO) and peroxidase (POD)) in aphid tissues was analysed for three constant temperatures. The results of our research showed that the enzymatic activity of aphids (measured as the activity of antioxidant, detoxifying and oxidoreductive enzymes) was mainly determined by the type of morph. We observed a strong positive correlation between the activity of the detoxifying and oxidoreductive enzymes and aphids' development, and a negative correlation between the activity of the antioxidant enzymes and aphids' development. Moreover, the study showed that an increase in temperature caused changes in enzyme activity (especially SOD, CAT and $\beta$-glucosidase), which was highest at $28{ }^{\circ} \mathrm{C}$, in both nymphs and adults. Additionally, a strong positive correlation between metabolic activity (heat flow measured by microcalorimeter) and longevity was observed, which confirmed the relationship between these characteristics of aphids. The antioxidant enzyme system is more efficient in aphid nymphs, and during aphid development the activity of antioxidant enzymes decreases. The antioxidant enzyme system in aphids appears to deliver effective protection for nymphs and adults under stressful conditions, such as high temperatures.
\end{abstract}

Keywords: aphids; enzymatic markers; oxidative stress; developmental stages

\section{Introduction}

Increasing ambient temperature can cause changes in insect biology, behaviour and development, and also changes at cellular and metabolic levels, disrupting the natural balance between ROS production and reduction [1-5]. Oxidative stress (OS) is caused by an excessive amount of ROS in an insect's body, the generation of which is increased due to stresses such as thermal stress. Temperature affects the intensity of respiration and the rate of ROS formation, the amount of which increases with the consumption of oxygen by organisms [6-11]. In order to defend against the effects of ROS, organisms have a number of defense mechanisms [12]. Herbivores, such as chewing insects [6,13-15] and sucking-piercing insects, which include aphids [16-20], possess a system of enzymes, the role of which is to destroy toxic ROS. 
Aphids develop physiological strategies to adapt to stress factors and one of the most rapid responses to abiotic stress is their enzymatic system - a rapid cascade of interacting antioxidative, oxidoreductive and detoxification enzymes $[6,19,21-23]$. The main antioxidant enzymes, which appear in all aerobic organisms and are responsible for the neutralisation of ROS, are superoxide dismutase (SOD) and catalase (CAT) [20,24]. SOD catalyses the decomposition of the superoxide radical into oxygen and hydrogen peroxide, thus preventing the formation of toxic hydroxyl radicals [7]. CAT catalyses the reactions of the decomposition of $\mathrm{H}_{2} \mathrm{O}_{2}$ into molecular oxygen and water. In aphids, this occurs mainly in the midgut, the middle part of the digestive system, which is the "centre" of $\mathrm{H}_{2} \mathrm{O}_{2}$ production $[18,25]$. Detoxification enzymes, $\beta$-glucosidase and glutathione $S$-transferase (GST) play an important role in the insect's resistance to secondary metabolites of the host plants and other xenobiotics [26]. GST are a group of multifunctional enzymes that catalyse the conjugation of glutathione with a wide range of endogenous compounds and xenobiotics for detoxification, protection against oxidative damage, isomerisation, and intracellular transport [27]. $\beta$-glucosidase hydrolyses the breakdown of o-glycosyl bonds; activity of this enzyme is strongly related to the chemical composition of the host plant [28] Environmental stresses can lead to a chemical modification of the phloem sap, which leads to a drop in glucose levels, resulting in the displacement and initiation of feeding by the aphids in the mesophyll cells. The aphids begin to take up other sugars, such as sucrose, which are dehydrolysed by $\beta$-glucosidase to glucose and fructose. Under stress, the phloem probing phases are disturbed, which leads to the take up of more sucrose by the aphids [29]. The main task of oxidoreductive enzymes (which include, for example, polyphenol oxidase (PPO) and peroxidase (POD)) is to minimise plant defense mechanisms targeting herbivorous insects, by reducing plant phenolic compounds and their derivatives taken with plant nourishment [30]. The mechanism of the enzymatic defense system allows insects to neutralise the effects of OS in tissues [6]. Temperature may also affect the lifespan of insects by changing their energy status and the generation of molecular damage [31,32]. Due to the coordinated interaction of antioxidative, oxidoreductive and detoxification enzymes, and an increase in metabolic rate, the insects can protect themselves against excessive induction of ROS during high temperatures [33] The consequence of this may be a shortening of the insect's lifespan [32].

Aphids (Hemiptera, Aphidoidea) are herbivores with the status of major pests for both crops and ornamental plants. Aphis pomi (De Geer, 1773) is an oligophagous aphid that feeds on trees and shrubs of the Rosaceae family such as apple, pear and quince. The species often forms large, strong honey-dewing colonies, which causes leaves to curl. Macrosiphum rosae, the rose aphid, (Linnaeus, 1758) is also an oligophagous that feeds on plants of the Rosaceae family, but particularly on decorative plants. Cinara (Cupressobium) cupressi (Buckton, 1881), the cypress aphid, is a voracious pest of Cupressus spp. and other Cupressaceae, for example Juniperus or Thuja, which are currently distributed worldwide. All these species are a serious pest to economically important plants grown in commercial orchards, nursery stock, parks and gardens, and cause significant damage to cultivated and ornamental plants around the globe [34-39].

Stage-specific thermal tolerance is common in insects, especially for species with complex life stages for which specific environmental factors could lead to a variation in responses across life stages [40,41]. In contrast, hemimetabolous insects, such as aphids, where nymphs and adults live in colonies, can be subjected to the same ranges of temperature factors. It is unclear how an increase in temperature will affect the different stages of development of aphids. The aim of the study was (1) to determine the differences in the activity of antioxidant (superoxide dismutase and catalase), detoxifying (glutathione S-transferase and $\beta$-glucosidase) and oxidoreductive (peroxidase and polyphenol oxidase) enzymes of nymphs and adult aphids, (2) to determine the changes in the activity of enzymatic markers in response to the temperature increase, and (3) the correlation between metabolic activity (as a heat flow measured by microcalorimeter) and longevity of aphids was tested. We verified the hypotheses: (1) the enzymatic activity (SOD, CAT, GST, 
$\beta$-glucosidase, PPO and POD) of nymphs and adult aphids differ, and (2) the enzymatic defense response (changes in the activity of SOD, CAT, GST, $\beta$-glucosidase, PPO and POD) of nymphs and adult aphids differ depending on the temperature. Additionally, we expected (3) a strong positive correlation between metabolic activity and longevity, which would confirm the relationship of these characteristics of aphids.

\section{Materials and Methods}

\subsection{Aphids}

A. pomi, M. rosae and C. cupressi were used in the experiments and came from the stock culture of the University of Rzeszow. The aphids were grown on the same host plant species (Chaenomeles japonica, Rosa rugosa, Juniperus scopulorum) that were used in the experiment. The experimental aphids were bred at $16 \mathrm{~L}: 8 \mathrm{D}$ photoperiods, $20 \pm 1{ }^{\circ} \mathrm{C}$ and $60 \% \pm 5 \%$ humidity, and were kept in an MLR-351H climatic chamber (Sanyo Corp., Japan) under controlled conditions. Both adult wingless females and 3rd or 4th nymphs of the tested species were used for the experiments.

\subsection{Host Plants}

The host plants for A. pomi were seedlings of Chaenomeles japonica, for M. rosae, the host plants were seedlings of Rosa rugosa and for C. cupressi the host plants were Juniperus scopulorum. The plants were free of pathogens, were set in $30 \mathrm{~cm} \times 30 \mathrm{~cm} \times 30 \mathrm{~cm}$ pots (Ch. japonica and R. rugosa) or $20 \mathrm{~cm} \times 20 \mathrm{~cm} \times 20 \mathrm{~cm}$ (J. scopulorum), and were grown for two weeks at $20^{\circ} \mathrm{C}$ to acclimatise before the experiment.

\subsection{Effect of Temperature on the Enzymatic Activity in Nymph and Adult Aphid Tissues}

The experiment was performed at three constant temperatures $\left(20,25\right.$ or $\left.28^{\circ} \mathrm{C}\right)$ under unvarying conditions, independently of each other, as previously described. Thirty adults or 30 nymphs of each species were placed on a host plant. The insects fed on the host plant for 0 (sample taken before starting the experiment), 24, 48, 72, 96 or $336 \mathrm{~h}$ ( 2 weeks). After the specified time elapsed, the aphids were harvested and frozen in liquid nitrogen. The experiments were carried out in 3 replications. Samples were stored at $-85^{\circ} \mathrm{C}$ (Freezer VXS 490) until analysis.

The frozen insects (30 individuals per sample) were placed in a phosphate buffer $(0.1 \mathrm{M}, \mathrm{pH} 7.0)$ and homogenised at $0{ }^{\circ} \mathrm{C}$. The resulting homogenate was centrifuged (Eppendorf Centrifuge $5810 \mathrm{R}$ ) at $4{ }^{\circ} \mathrm{C}$. The supernatant obtained was used to determine enzymatic activity according to protocols described in our previous paper by Durak et al. [42] and Dampc et al. [33].

Absorbance was measured with a TECAN Infinite 200 microplate reader, and CAT was measured using a Carry 50 spectrophotometer. The wavelengths for measuring the absorbance of individual enzymes are in parentheses, incubation times are described in Dampc et al. [33].

\subsubsection{Antioxidant Enzymes}

Superoxide dismutase (SOD) activity was measured in phosphate buffer ( $\mathrm{pH}$ 7.8) using the method described by Wang et al. [14]. The reaction mixture contained homogenate, solution of nitro blue tetrazolium xanthine solution and xanthine oxidase solution $(560 \mathrm{~nm})$. Catalase activity (CAT) activity was determined using the standard method according to Aebi [43], in phosphate buffer ( $\mathrm{pH} 7.0)$ with $\mathrm{H}_{2} \mathrm{O}_{2}$ solution $(240 \mathrm{~nm})$.

\subsubsection{Detoxifying Enzymes}

The level of $\beta$-glucosidase was determined in phosphate buffer ( $\mathrm{pH}$ 5.8) with $\mathrm{p}$ nitrophenyl- $\beta$-D-glucopyranoside solution $(400 \mathrm{~nm}$ ) according to the reactions described by Katagiri [44]. Glutathione S-transferase (GST) activity was determined as per Leszczynski and Dixon [45] in phosphate buffer ( $\mathrm{pH}$ 7.0) with 1-chloro-2.4-dinitrobenzene and GSH solution $(340 \mathrm{~nm})$. 


\subsubsection{Oxidoreductive Enzymes}

Polyphenol oxidase (PPO) activity was determined in phosphate buffer ( $\mathrm{pH}$ 7.4) with catechol $(460 \mathrm{~nm})$ using the method described by Miles [46] with a slight modification from Laurema et al. [47]. Peroxidase (POD) activity was determined by the standard method according to Fehrman and Dimond [48], in phosphate buffer (pH 7.0) with pyrogallol (430).

\subsubsection{Protein Content in Aphid Extracts}

Protein content was measured by the standard method described by Lowry et al. [49].

\subsection{Effect of Temperature on Aphid Longevity}

To determine longevity, 12 aphids of A. pomi and C. cupressi were bred separately on the host plants from birth to death, at selected temperatures $\left(20,25\right.$, or $\left.28^{\circ} \mathrm{C}\right)$. Metabolic activity of A. pomi and C. cupressi was measured at 20, 25, and $28^{\circ} \mathrm{C}$ using a TAM III isothermal calorimeter equipped with TAM Assistant Software (TA Instruments). Twenty $A$. pomi aphids were placed on a young leaf and 5 C. cupressi were placed on a piece of juniper, then into $4.0 \mathrm{~mL}$ calorimetric ampoules with $0.25 \mu \mathrm{L}$ of water. Thermal power curves were recorded over $4 \mathrm{~h}$ due to the rapid consumption of oxygen in the ampule by the $C$. cupressi. The metabolic activity of the aphids was calculated, as described by Dampc et al. [33]. Twelve independent repetitions for each specimen were carried out.

\subsection{Statistical Analyses}

To compare the averaged values of the enzymatic activity, we used a factorial ANOVA with statistical significance at $p<0.05$. Averaged values of enzymatic activity were compared using three explanatory factors: temperature $\left(20,25\right.$ and $\left.28^{\circ} \mathrm{C}\right)$, time $(0,24,48,72,96$ and $336 \mathrm{~h}$ ) and type of morph (nymph and adult). The analyses were performed separately for each enzyme and each aphid species. In order to reveal the links between patterns of enzyme activity, developmental stage and temperature, we analysed the enzymatic activity of nymphs and adults of three aphid species in different temperatures by principal component analysis (PCA). The PCA reduces the dimensionality of the complex enzymatic response of aphids and acquires the core of the data in a few principal components, which carry the most variation in the data. The significant role of the developmental stage and temperature in differentiating the enzymatic response along the first and second axis of PCA (hereafter, PC1 and PC2) were confirmed by a two-way ANOVA. In order to explain the pattern of aphid enzymatic response depending on developmental stage and temperature, we examined the relationships between the enzyme characteristics (individual enzyme activity and activity of groups of enzymes) and the differential in aphid's enzymatic response represented by the PCA axis scores. For this purpose, Spearman rank correlation tests were used. To obtain the enzyme characteristics, the values for enzymes measured for each species were averaged and assigned to the following three groups: group 1- antioxidant (G1), group 2-detoxifying (G2), and group 3-oxidoreductive (G3). The Spearman correlation was also used to determine the relationships between heat flow and the longevity of aphids. All statistical analyses were done using Statistica version 13 programme (TIBCO Software Inc., 2017, http:/ / statistica.io; accessed on 10 May 2021) and PAST 3 software.

\section{Results}

\subsection{Antioxidant Enzyme Activity of Nymphs and Adult Aphids during Temperature Increase}

The analysis of the SOD activity of the three species of aphid showed it was dependent on all examined factors: temperature, time and type of morph. The activity of SOD in A. pomi was significantly influenced by the temperature, time and type of morph studied (Table 1). Such relationships were also observed in M. rosae and C. cupressi (Table 1). There was also a significant interaction between temperature, time and morph type on the level of SOD activity in the studied species (Table 1, Figure S1). Significant differences in SOD activity were observed between adults and nymphs in all examined species, and the highest activity of this enzyme was found in nymphs. The analysis of CAT activity in the studied 
species showed its dependence on temperature, time and type of morph. All factors had a significant influence on the changes in CAT activity observed in A. pomi, M. rosae and C. cupressi (Table 1, Figure S1). Similarly, in the case of SOD, the significant influence of the interaction between temperature, time and type of morph was demonstrated, and was visible in all tested species A. pomi, M. rosae, and C. cupressi (Table 1). Significant differences were observed between the CAT activity of nymphs and adults.

Table 1. Analysis of enzymatic activity in the tissues of three species of aphid: Aphis pomi, Macrosiphum rosae and Cinara cupressi. ANOVA was used to test differences between average enzymatic activities in different conditions $(p<0.05)$. (T-temperature, $\mathrm{t}$-time, $\mathrm{m}$-type of morph).

\begin{tabular}{|c|c|c|c|c|c|c|}
\hline & SOD & CAT & GST & $\beta$-Glucosidase & POD & PPO \\
\hline \multicolumn{7}{|l|}{ Aphis pomi } \\
\hline $\mathrm{T}$ & $\mathrm{F}_{(2,72)}=4.99 * * *$ & $\mathrm{~F}_{(2,72)}=72.42 * * *$ & $\mathrm{~F}_{(2,72)}=20.61^{* * *}$ & $\mathrm{~F}_{(2,72)}=534.30^{* * *}$ & $\mathrm{~F}_{(2,72)}=31.95^{* * *}$ & $\mathrm{~F}_{(2,72)}=64.17^{* * *}$ \\
\hline $\mathrm{t}$ & $\mathrm{F}_{(5,72)}=9.96^{* * *}$ & $\mathrm{~F}_{(5,72)}=114.14 * * *$ & $\mathrm{~F}_{(5,72)}=6.42 * * *$ & $\mathrm{~F}_{(5,72)}=474.83^{* * *}$ & $\mathrm{~F}_{(5,72)}=26.70^{* * *}$ & $\mathrm{~F}_{(5,72)}=64.61^{* * *}$ \\
\hline $\mathrm{m}$ & $\mathrm{F}_{(1,72)}=2937.76^{* * *}$ & $\mathrm{~F}_{(1,72)}=677.21 * * *$ & $\mathrm{~F}_{(1,72)}=555,58^{* * *}$ & $\mathrm{~F}_{(1,72)}=14.82 * * *$ & $\mathrm{~F}_{(1,72)}=970.45^{* * *}$ & $\mathrm{~F}_{(1,72)}=13.02 * * *$ \\
\hline $\mathrm{T} \times \mathrm{m}$ & $\mathrm{F}_{(2,72)}=3.63^{* * *}$ & $\mathrm{~F}_{(2,72)}=32.87^{* * *}$ & $\mathrm{~F}_{(2,72)}=4.31 *$ & $\mathrm{~F}_{(2,72)}=0.18$ & $\mathrm{~F}_{(2,72)}=2.01$ & $\mathrm{~F}_{(2,72)}=11.56^{* * *}$ \\
\hline $\mathrm{T} \times \mathrm{t}$ & $\mathrm{F}_{(10,72)}=1.72$ & $\mathrm{~F}_{(10,72)}=20.21^{* * *}$ & $\mathrm{~F}_{(10,72)}=1.85$ & $\mathrm{~F}_{(10,72)}=54.52 * * *$ & $\mathrm{~F}_{(10,72)}=3.58^{* * *}$ & $\mathrm{~F}_{(10,72)}=5.62 * * *$ \\
\hline $\mathrm{t} \times \mathrm{m}$ & $\mathrm{F}_{(5,72)}=2.87^{* *}$ & $\mathrm{~F}_{(5,72)}=20.51^{* * *}$ & $\mathrm{~F}_{(5,72)}=2.83 *$ & $\mathrm{~F}_{(5,72)}=4.33^{* * *}$ & $\mathrm{~F}_{(5,72)}=5.28^{* * *}$ & $\mathrm{~F}_{(5,72)}=14.41 * * *$ \\
\hline $\mathrm{T} \times \mathrm{t} \times \mathrm{m}$ & $\mathrm{F}_{(10,72)}=1.90 *$ & $\mathrm{~F}_{(10,72)}=6.29 * * *$ & $\mathrm{~F}_{(10,72)}=1.07$ & $\mathrm{~F}_{(10,72)}=4.30^{* * *}$ & $\mathrm{~F}_{(10,72)}=1.59$ & $\mathrm{~F}_{(10,72)}=26.65^{* * *}$ \\
\hline \multicolumn{7}{|c|}{ Macrosiphum rosae } \\
\hline $\mathrm{T}$ & $\mathrm{F}_{(2,72)}=63.86^{* * *}$ & $\mathrm{~F}_{(2,72)}=2.33^{* *}$ & $\mathrm{~F}_{(2,72)}=5.39 * *$ & $\mathrm{~F}_{(2,72)}=7.66^{* * *}$ & $\mathrm{~F}_{(2,72)}=6.25 * *$ & $\mathrm{~F}_{(2,72)}=15.98^{* * *}$ \\
\hline$t$ & $\mathrm{~F}_{(5,72)}=43.43^{* * *}$ & $\mathrm{~F}_{(5,72)}=32.83 * * *$ & $F_{(5,72)}=2.86^{*}$ & $F_{(5,72)}=1.39$ & $\mathrm{~F}_{(5,72)}=19.10^{* * *}$ & $\mathrm{~F}_{(5,72)}=3.98 * *$ \\
\hline $\mathrm{m}$ & $\mathrm{F}_{(1,72)}=976.55^{* * *}$ & $\mathrm{~F}_{(1,72)}=37.78^{* * *}$ & $\mathrm{~F}_{(1,72)}=7884.39 * * *$ & $\mathrm{~F}_{(1,72)}=20.58^{* * *}$ & $\mathrm{~F}_{(1,72)}=2351.88^{* * *}$ & $\mathrm{~F}_{(1,72)}=108 \cdot 12^{* * *}$ \\
\hline $\mathrm{T} \times \mathrm{m}$ & $\mathrm{F}_{(2,72)}=84.61 * * *$ & $\mathrm{~F}_{(2,72)}=0.43^{* *}$ & $\mathrm{~F}_{(2,72)}=0.10$ & $\mathrm{~F}_{(2,72)}=1.17$ & $\mathrm{~F}_{(2,72)}=4.24 *$ & $\mathrm{~F}_{(2,72)}=0.14$ \\
\hline $\mathrm{T} \times \mathrm{t}$ & $\mathrm{F}_{(10,72)}=15.83^{* * *}$ & $\mathrm{~F}_{(10,72)}=2.18^{* *}$ & $\mathrm{~F}_{(10,72)}=2.71^{* *}$ & $\mathrm{~F}_{(10,72)}=1.62$ & $\mathrm{~F}_{(10,72)}=2.21^{*}$ & $F_{(10,72)}=2.43 *$ \\
\hline $\mathrm{t} \times \mathrm{m}$ & $\mathrm{F}_{(5,72)}=34.01 * * *$ & $\mathrm{~F}_{(5,72)}=10.28^{* * *}$ & $\mathrm{~F}(5,72)=2.09$ & $\mathrm{~F}_{(5,72)}=3.22 *$ & $\mathrm{~F}_{(5,72)}=17.58^{* * *}$ & $\mathrm{~F}_{(5,72)}=3.55^{* *}$ \\
\hline $\mathrm{T} \times \mathrm{t} \times \mathrm{m}$ & $\mathrm{F}_{(10,72)}=14 \cdot 17^{* * *}$ & $\mathrm{~F}_{(10,72)}=3.81^{* * *}$ & $\mathrm{~F}_{(10,72)}=2.68 * *$ & $\mathrm{~F}_{(10,72)}=1.27$ & $\mathrm{~F}_{(10,72)}=2.33^{*}$ & $\mathrm{~F}_{(10,72)}=3.03 * *$ \\
\hline \multicolumn{7}{|c|}{ Cinara cupressi } \\
\hline $\mathrm{T}$ & $\mathrm{F}_{(2,72)}=118.67^{* * *}$ & $\mathrm{~F}_{(2,72)}=335.74^{* * *}$ & $\mathrm{~F}_{(2,72)}=154.28^{* * *}$ & $\mathrm{~F}_{(2,72)}=13.74^{* * *}$ & $\mathrm{~F}_{(2,72)}=114.34^{* * *}$ & $\mathrm{~F}_{(2,72)}=60.89 * * *$ \\
\hline $\mathrm{t}$ & $\mathrm{F}_{(5,72)}=17.43^{* * *}$ & $\mathrm{~F}_{(5,72)}=529.52^{* * *}$ & $\mathrm{~F}_{(5,72)}=85.47^{* * *}$ & $\mathrm{~F}_{(5,72)}=6.00^{* * *}$ & $\mathrm{~F}_{(5,72)}=60.27^{* * *}$ & $\mathrm{~F}_{(5,72)}=12.05^{* * *}$ \\
\hline $\mathrm{m}$ & $\mathrm{F}_{(1,72)}=1729.37^{* * *}$ & $\mathrm{~F}_{(1,72)}=378.08^{* * *}$ & $\mathrm{~F}_{(1,72)}=8183.41^{* * *}$ & $\mathrm{~F}_{(1,72)}=2467.09^{* * *}$ & $\mathrm{~F}_{(1,72)}=2661.945^{* * *}$ & $\mathrm{~F}_{(1,72)}=2297.45^{* * *}$ \\
\hline $\mathrm{T} \times \mathrm{m}$ & $\mathrm{F}_{(2,72)}=24.44^{* * *}$ & $\mathrm{~F}_{(2,72)}=123.77 * * *$ & $\mathrm{~F}_{(2,72)}=21.18^{* * *}$ & $\mathrm{~F}_{(2,72)}=6.37 * *$ & $\mathrm{~F}_{(2,72)}=124.26^{* * *}$ & $\mathrm{~F}_{(2,72)}=37.06^{* * *}$ \\
\hline $\mathrm{T} \times \mathrm{t}$ & $\mathrm{F}_{(10,72)}=7.57^{* * *}$ & $\mathrm{~F}_{(10,72)}=114.84 * * *$ & $\mathrm{~F}_{(10,72)}=9.08^{* * *}$ & $\mathrm{~F}_{(10,72)}=4.07^{* * *}$ & $\mathrm{~F}_{(10,72)}=15.27^{* * *}$ & $\mathrm{~F}_{(10,72)}=19.35^{* * *}$ \\
\hline $\mathrm{t} \times \mathrm{m}$ & $\mathrm{F}_{(5,72)}=7.67^{* * *}$ & $\mathrm{~F}_{(5,72)}=173.21^{* * *}$ & $\mathrm{~F}_{(5,72)}=48.55^{* * *}$ & $\mathrm{~F}_{(5,72)}=3.16^{*}$ & $\mathrm{~F}_{(5,72)}=53.85^{* * *}$ & $\mathrm{~F}_{(5,72)}=17.96^{* * *}$ \\
\hline $\mathrm{T} \times \mathrm{t} \times \mathrm{m}$ & $\mathrm{F}_{(10,72)}=3.17 * *$ & $\mathrm{~F}_{(10,72)}=53.65^{* * *}$ & $\mathrm{~F}_{(10,72)}=3.46^{* * *}$ & $\mathrm{~F}_{(10,72)}=1.72$ & $\mathrm{~F}_{(10,72)}=13.71^{* * *}$ & $\mathrm{~F}_{(10,72)}=11.26^{* * *}$ \\
\hline
\end{tabular}

\subsection{Detoxifying Enzyme Activity of Nymphs and Adult Aphids during Temperature Increase}

$\beta$-glucosidase activity was dependent on temperature, time and type of morph in A. pomi and C. cupressi. However, time did not affect the activity of this enzyme in $M$. rosae. In contrast to time, the type of morph significantly influenced the activity of this enzyme in all species. $\beta$-glucosidase activity varied between nymphs and adults in all species (Table 1 , Figure S1). The GST activity of aphids was influenced by the temperature, time and type of morph in all tested species (Table 1). However, significant interactions between these three factors were only found in $M$. rosae and C. cupressi. We found differences in the activity of this enzyme between different morphs (Table 1, Figure S1).

\subsection{Oxidoreductive Enzyme Activity of Nymphs and Adult Aphids during Temperature Increase}

POD activity was significantly dependent on the three factors: temperature, time and morph type in all the studied species, but a significant influence of the interaction 
between temperature, time and type of morph was observed in M. rosae and C. cupressi (Table 1, Figure S1). In all tested aphid species, PPO activity was significantly dependent on temperature, time and morph type (Table 1, Figure S1). We also observed significant interactions between these factors in individual species.

\subsection{Enzymatic Differences between Nymphs and Adult Aphids during Temperature Increase}

The PCA of all investigated enzymes in the tissues of three species of aphids (Aphis pomi, Macrosiphum rosae and Cinara cupressi) is presented in Figure 1. The first two PCA axes covered $84.33 \%$ of the variance in the data. The first PCA axis (which explained $76.9 \%$ of the variation), with a high probability, separated samples according to the developmental stage (type of morph) and to a lesser extent, temperature. This was supported by a twoway ANOVA test that confirmed the dominant role of the developmental stage, and the subdominant role of temperature in explaining enzymatic variability (Table 2). Moreover, PC1 had a very strong, positive correlation with enzymes: GST, POD, PPO and groups of enzymes: G2 and G3 (detoxifying and oxidoreductive), as well as a strong, negative correlation with CAT (Table 3, Figure 2). The second PCA axis explained only $7.4 \%$ of the variation and segregated the samples mainly according to the temperature change and, in a smaller proportion, according to the developmental stage (Table 2). PC2 had a strong, positive correlation with enzymes: SOD and $\beta$-glucosidase, as well as a group of enzymes, G1 (antioxidant) (Table 3, Figure 2). This analysis showed a clear separation of the enzyme activities of nymphs and adult aphids, and also the physiological defense of nymphs and adult aphids against temperature stress. The main role in the enzymatic defense response of nymphs is played by antioxidant enzymes (G1) (Figure 1A), the activity of which is correlated with the type of morph (nymph), and also had a strong correlation with temperature (Table 3, Figure 2). The detoxifying (G2) and oxidoreductive (G3) enzymes showed a higher correlation with type of morphs—adults (Figure 1A, Table 3, Figure 2). The defense responses of both nymphs and adults were dependent on temperature (Figure 1B). The enzymatic activity increased with increasing temperature and was clearly higher at $28{ }^{\circ} \mathrm{C}$ than at $20^{\circ} \mathrm{C}$ for both nymph and adults (Figure $1 \mathrm{~B}$ ).

A

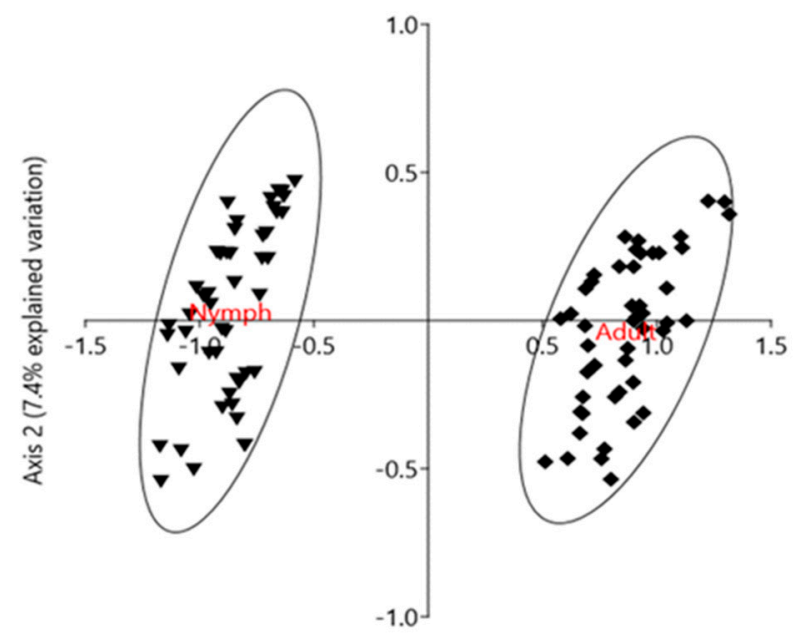

Axis 1 (76.9\% explained variation)
B

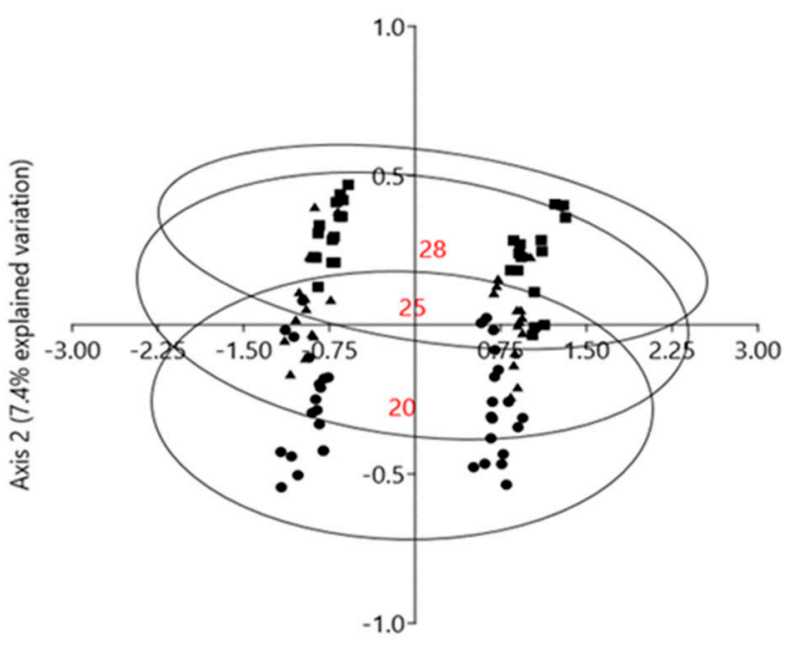

Axis 1 (76.9\% explained variation)

Figure 1. Principal component analysis (PCA) of enzyme data from three aphid species. (A) The first axis (PC1) segregated the enzyme data according to aphid developmental stage, and to a lesser extent, according to temperature (inverted triangle-nymphs, diamond-adults). (B) The second axis (PC2) segregated the enzyme data according to temperature (dot-20 ${ }^{\circ} \mathrm{C}$, triangle $-25^{\circ} \mathrm{C}$, square $-28^{\circ} \mathrm{C}$ ). The groups are marked with $95 \%$ ellipses. 


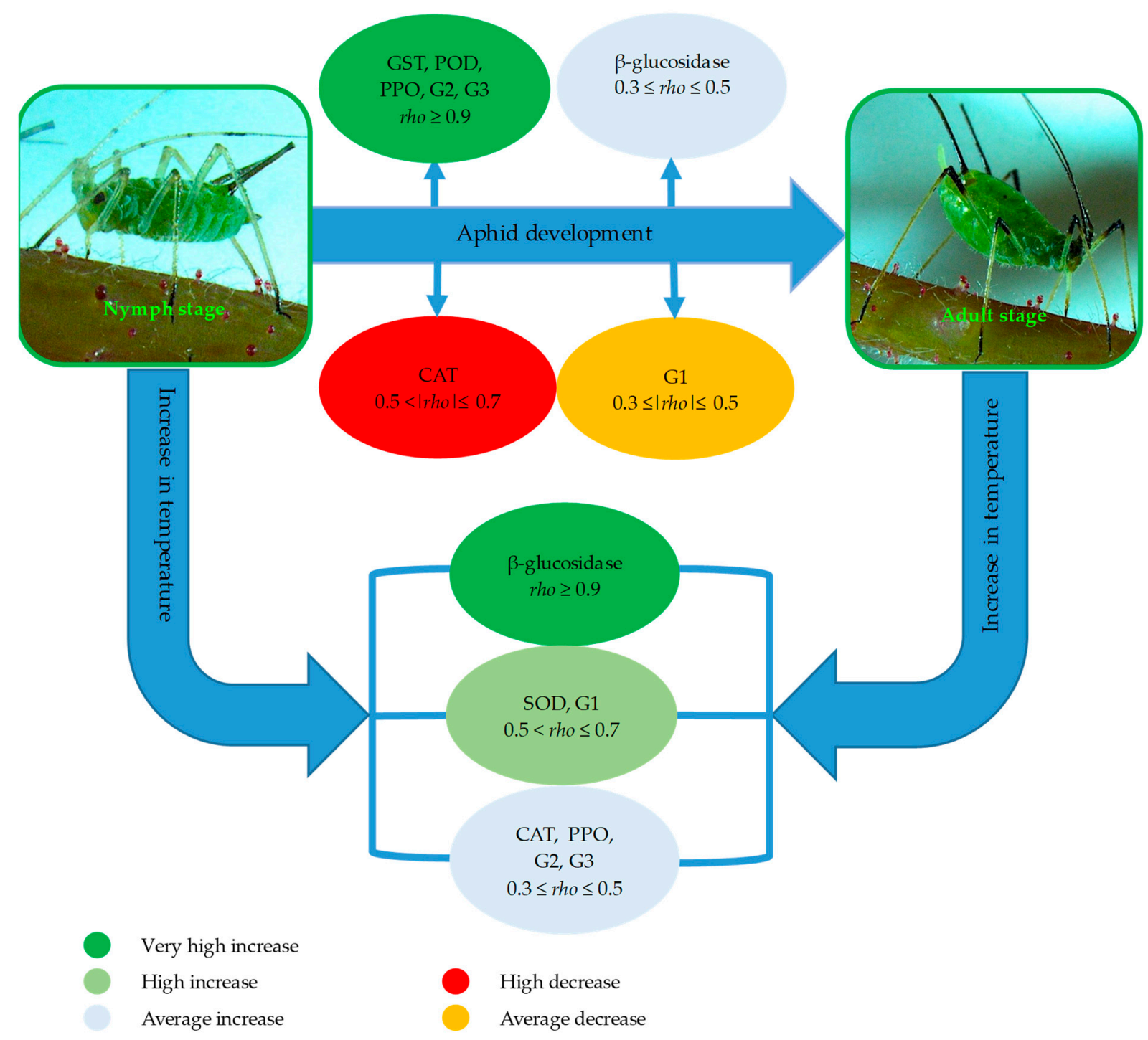

Figure 2. Schematic diagram of the main changes in aphid's enzyme activity in response to course of development and temperature. G1, G2 and G3 groups of enzymes: antioxidant, detoxifying and oxidoreductive, respectively. Enzyme activity responses were ranked based on Spearman's rho correlation coefficients given in Table 3. Correlation coefficients with values indicating at least an average correlation $(0.3 \leq r h o)$ were taken into consideration. See Table 3 for detailed results.

Table 2. ANOVA test results confirm that the first component (PC1) mainly shows that the strong differentiation of aphid enzymatic response depends on developmental stage (type of morph: nymphs, adults), and the second component (PC2) mainly shows that the differentiation of aphid enzymatic response depends on temperature.

\begin{tabular}{cc}
\hline & Test Score (F) \\
\hline PC1 & \\
Temperature $(\mathrm{T})$ & $38.31^{* * *}$ \\
Morph $(\mathrm{m})$ & $4635.07^{* * *}$ \\
$\mathrm{~T} \times \mathrm{m}$ & $3.31^{*}$ \\
PC2 & $96.06^{* * *}$ \\
Temperature $(\mathrm{T})$ & $4.32^{*}$ \\
Morph $(\mathrm{m})$ & 0.85 \\
$\mathrm{~T} \times \mathrm{m}$ &
\end{tabular}

${ }^{*} p<0.05 ;{ }^{* * *} p<0.001$. 
Table 3. Correlation between enzyme data from aphid species (individual enzymes and specific groups of enzymes) and PCA axes that represent changes in enzyme data depending on aphid developmental stage and temperature (Spearman rank correlation test).

\begin{tabular}{ccc}
\hline & \multicolumn{2}{c}{ Spearman's rho Correlation Coefficients } \\
\cline { 2 - 3 } & PC1 & PC2 \\
\hline Enzymes & & \\
SOD & $-0.27^{* * *}$ & $0.64^{* * *}$ \\
CAT & $-0.55^{* * *}$ & $0.37^{* * *}$ \\
B-glucosidase & $0.37^{* * *}$ & $0.88^{* * *}$ \\
GST & $0.88^{* * *}$ & $0.24^{*}$ \\
POD & $0.90^{* * *}$ & $0.12^{* * *}$ \\
PPO & $0.95^{* * *}$ & $0.30^{* *}$ \\
Groups of enzymes & $-0.37^{* * *}$ & $0.65^{* * *}$ \\
G1 (antioxidant enzymes) & $0.90^{* * *}$ & $0.35^{* * *}$ \\
G2 (detoxifying enzymes) & $0.97^{* * *}$ & $0.30^{* *}$ \\
G3 (oxidoreductive enzymes) & $* p<0.05^{* * *} p<0.01^{* * *} p<0.001$. & \\
\hline
\end{tabular}

\subsection{Effect of Temperature on the Longevity of Aphids}

Changes were found in the metabolic heat of M. rosae and C. cupressi related to temperature increase, and these changes negatively impacted the lifespan of the aphids. Spearman's rank correlation coefficient values were rho $=-0.62,(p<0.001)$ for $M$. rosae and $r h o=-0.71$ for $C$. cupressi $(p<0.001)$, and confirmed the strong negative correlation between heat flow and longevity.

\section{Discussion}

The effects of stress caused by temperature increase on insects may depend on many factors, such as frequency, amplitude, duration of the stress, sex, or developmental stage of the insect $[8,50,51]$. In aphids, due to their relatively short development period and colony life, all development stages may be exposed to stress caused by temperatures exceeding their thermal optimum. The activity of the tested enzymes in the three aphid species increased, which suggests the involvement of these enzymes in reducing the adverse effects of ROS generated by thermal stress and the defensive function (Figure 1, Figure S1).

Our research has shown that the enzymatic activity of nymphs and adults differ from each other (Figure 1A). The enzymatic defense response varied depending on the temperature (Figure 1B). The results of our study demonstrate that the antioxidant enzyme system is more efficient in aphid nymphs and provides them with quick and effective protection against stress factors. At the same time, oxidoreductive and detoxifying enzymes are more active in adults. This could suggest that the nymphs' system of detoxifying and oxidoreductive enzymes is less efficient, and hence, nymphs may be less effective in degrading toxic substances. The efficient operation of enzyme groups provides nymphs with effective protection against stress. The high activity of antioxidant enzymes enables the nymphs to mature under stressful conditions, such as high temperatures (Figure 1).

Stage-specific thermal tolerance is very common in insects [41], but the larvae of different orders of insects respond to stress differently. Some authors have shown that the enzymatic activity of larvae is higher than that of adults. The potential role of antioxidant enzymes in preventing damage from abiotic stresses during growth in the third to sixthinstar larval stages was noted in larvae of Lepidoptera, and high stage-specific antioxidative enzyme activity was also reported in, for example, Chilo suppressalis. For the larvae of Lepidoptera, upregulation of CsCAT enhanced the defense response of C. suppressalis by weakening the effects of environmental stresses. CAT was expressed highly in the third to sixth-instar larval stages, which supports the potential role of the enzyme in preventing damage from abiotic stresses during the developmental process [52]. In addition, activity of this enzyme was higher in larvae, as a response to temperature stress. Stage-specific 
antioxidative enzyme activity related to the sensitivity of stages to heat stress was also characteristic for beetles Ophraella communa [8]. Furthermore, in honeybees Apis mellifera, SOD activity was higher in larvae than in the adult stage [53]. In contrast, high enzyme activity levels in the adult of Osmia bicornis were related, which was explained by intensified mitochondrial activity due to high energy demands at this stage, especially during flight because the flight muscles are exposed to high levels of ROS [23,54]. Also, Krishnan et al. $[15,24]$ noted a higher antioxidant potential in adults of Leptinotarsa decemlineata than in the larval stage. Thus, these insects were able to adapt quickly to increased oxidative stress arising from plant prooxidant allelochemicals by regulation of antioxidant enzyme activities [15]. Previous studies have shown that the antioxidant mechanism of aphids depends on the host plant; differences were not only observed between aphid species, but also between populations of the same species that inhabited different hosts [19].

The increase in temperature positively influenced the aphid metabolism, causing an increase in heat energy. As a consequence, aphids living in higher temperatures had shorter longevity. Temperature is one factor widely discussed as affecting longevity and it can determine the lifespan of many model organisms, for example, fungi Saccharomyces cerevisiae [55], Caenorhabditis elegans [56] or Drosophila melanogaster [32]. For aphids, it has also been noted that there is a negative correlation between temperature and longevity [57-59], but in some aphids, the opposite effect was observed in relation to the optimum temperature of the species [60]. Our research confirmed that metabolic rate is an important determinant of longevity, thus indicating that an increase in ambient temperature will increase enzyme activity and shorten aphid longevity.

Our research shows that the effectiveness of aphid antioxidant, detoxifying and oxidoreductive mechanisms depends on many factors, such as the species of aphid, temperature, time and also type of morph. It seems that sap-feeding nymphs of aphids, show great adaptability due to their enzyme system, which is especially important in adaptation to host plants (in the case of generalists) as well as abiotic factors (temperature). Our results strongly correspond to the data obtained for the English grain aphid Sitobion avenae, which showed that the basal thermal tolerance of this species varied during development and was highest in the 3rd and 4th nymphs [61]. Changes in basal tolerance at the adult stage might result from a trade-off between heat tolerance and reproductive output, but may also result from behavioural thermoregulation abilities present in adult aphids [59]. Probably because the behavioural mechanisms of nymphs function poorly, we observed the need for high antioxidant activity of enzymes to effectively enable the protection of nymphs and allow them to continue development to maturity.

\section{Conclusions}

The enzymatic activity of aphids is mainly determined by the type of morph. The increase in temperature causes changes in enzyme activity, which is highest at $28^{\circ} \mathrm{C}$ in both nymphs and adults. Nymphs are characterised by an increased share of antioxidant enzymes, while in adults, detoxification and oxidoreductive enzymes dominate. An increase in energy activity caused by an increase in temperature will reduce the longevity of aphids.

Supplementary Materials: The following are available online at https://www.mdpi.com/article/ 10.3390/antiox10081181/s1, Figure S1: Principle component analysis (PCA) of enzymes data set of three aphid species. The groups are marked with $95 \%$ ellipses.

Author Contributions: Conceptualization, R.D.; methodology, R.D., J.D., T.D., M.K.-M., M.M.; formal analysis, R.D., T.D.; investigation, R.D., J.D., M.K.-M.; resources, R.D.; data curation, R.D.; writingoriginal draft preparation, R.D., T.D., J.D.; writing—review and editing, R.D.; visualization R.D., T.D.; supervision, R.D.; project administration, R.D.; funding acquisition, R.D. All authors have read and agreed to the published version of the manuscript.

Funding: Financial support for these studies was provided by the statutory fund of the University of Rzeszów. 
Institutional Review Board Statement: Not applicable.

Informed Consent Statement: Not applicable.

Data Availability Statement: The data presented in this study are available in the article. Additional data are available on request from the corresponding author.

Conflicts of Interest: The authors declare no conflict of interest.

\section{References}

1. Bale, J.S.; Gerday, C.; Parker, A.; Marahiel, M.A.; Shanks, I.A.; Davies, P.L.; Warren, G. Insects and low temperatures: From molecular biology to distributions and abundance. Philos. Trans. R. Soc. B Biol. Sci. 2002, 357, 849-862. [CrossRef]

2. Hullé, M.; Coeur d'Acier, A.; Bankhead-Dronnet, S.; Harrington, R. Aphids in the face of global changes. Comptes Rendus Biol. 2010, 333, 497-503. [CrossRef] [PubMed]

3. Rukke, B.A.; Sivasubramaniam, R.; Birkemoe, T.; Aak, A. Temperature stress deteriorates bed bug (Cimex lectularius) populations through decreased survival, fecundity and offspring success. PLoS ONE 2018, 13, e0193788. [CrossRef]

4. Harrington, R.; Fleming, R.A.; Woiwod, I.P. Climate change impacts on insect management and conservation in temperate regions: Can they be predicted? Agric. For. Entomol. 2001, 3, 233-240. [CrossRef]

5. Wu, Y.; Li, J.; Liu, H.; Qiao, G.; Huang, X. Investigating the impact of climate warming on phenology of aphid pests in China using long-term historical data. Insects 2020, 11, 167. [CrossRef]

6. Zhang, S.; Fu, W.; Li, N.; Zhang, F.; Liu, T.X. Antioxidant responses of Propylaea japonica (Coleoptera: Coccinellidae) exposed to high temperature stress. J. Insect Physiol. 2015, 73, 47-52. [CrossRef]

7. Jena, K.; Kumar Kar, P.; Kausar, Z.; Babu, C.S. Effects of temperature on modulation of oxidative stress and antioxidant defenses in testes of tropical tasar silkworm Antheraea mylitta. J. Therm. Biol. 2013, 38, 199-204. [CrossRef]

8. Chen, H.; Solangi, G.S.; Guo, J.; Wan, F.; Zhou, Z. Antioxidant responses of ragweed leaf beetle Ophraella communa (Coleoptera: Chrysomelidae) exposed to thermal stress. Front. Physiol. 2018, 9, 1-9. [CrossRef]

9. Zhang, G.H.; Liu, H.; Wang, J.J.; Wang, Z.Y. Effects of thermal stress on lipid peroxidation and antioxidant enzyme activities of the predatory mite, Neoseiulus cucumeris (Acari: Phytoseiidae). Exp. Appl. Acarol. 2014, 64. [CrossRef]

10. Kang, Z.-W.; Liu, F.-H.; Liu, X.; Yu, W.-B.; Tan, X.-L.; Zhang, S.-Z.; Tian, H.-G.; Liu, T.-X. The potential coordination of the heat-shock proteins and antioxidant enzyme genes of Aphidius gifuensis in response to thermal stress. Front. Physiol. 2017, 8, 1-12. [CrossRef]

11. Ali, A.; Rashid, M.A.; Huang, Q.Y.; Wong, C.; Lei, C.-L. Response of antioxidant enzymes in Mythimna separata (Lepidoptera: Noctuidae) exposed to thermal stress. Bull. Entomol. Res. 2017, 107, 382-390. [CrossRef]

12. Halliwell, B.; Gutteridge, J.M.C. Free Radicals in Biology and Medicine; Oxford University Press: New York, NY, USA, 2015; ISBN 9780198717478.

13. Barbehenn, R.V. Gut-based antioxidant enzymes in a polyphagous and a graminivorous grasshopper. J. Chem. Ecol. 2002, 28, 1329-1347. [CrossRef]

14. Wang, Y.; Oberley, L.W.; Murhammer, D.W. Antioxidant defense systems of two lipidopteran insect cell lines. Free Radic. Biol. Med. 2001, 30, 1254-1262. [CrossRef]

15. Krishnan, N.; Sehnal, F. Compartmentalization of oxidative stress and antioxidant defense in the larval gut of Spodoptera littoralis. Arch. Insect Biochem. Physiol. 2006, 63, 1-10. [CrossRef] [PubMed]

16. Figueroa, C.C.; Koenig, C.; Araya, C.; Santos, M.J.; Niemeyer, H.M. Effect of DIMBOA, a hydroxamic acid from cereals, on peroxisomal and mitochondrial enzymes from aphids: Evidence for the presence of peroxisomes in aphids. J. Chem. Ecol. 1999, 25, 2465-2475. [CrossRef]

17. Loayza-Muro, R.; Figueroa, C.C.; Niemeyer, H.M. Effect of two wheat cultivars differing in hydroxamic acid concentration on detoxification metabolism in the aphid Sitobion avenae. J. Chem. Ecol. 2000, 26, 2725-2736. [CrossRef]

18. Lukasik, I. Changes in activity of superoxide dismutase and catalase within cereal aphids in response to plant o-dihydroxyphenols. J. Appl. Entomol. 2007, 131, 209-214. [CrossRef]

19. Łukasik, I.; Goławska, S.; Wójcicka, A.; Goławski, A. Effect of host plants on antioxidant system of pea aphid Acyrthosiphon pisum. Bull. Insectol. 2011, 64, 153-158.

20. Łukasik, I.; Goławska, S. Effect of host plant on levels of reactive oxygen species and antioxidants in the cereal aphids Sitobion avenae and Rhopalosiphum padi. Biochem. Syst. Ecol. 2013, 51, 232-239. [CrossRef]

21. Bi, J.L.; Felton, G.W. Foliar oxidative stress and insect herbivory: Primary compounds, secondary metabolites, and reactive oxygen species as components of induced resistance. J. Chem. Ecol. 1995, 21, 1511-1530. [CrossRef] [PubMed]

22. Łukasik, I. Effect of host plant alternation on some adaptive enzymes of the bird cherry-oat aphid, Rhopalosiphum padi (L.). J. Pest Sci. 2009, 82, 203-209. [CrossRef]

23. Dmochowska-Ślęzak, K.; Giejdasz, K.; Fliszkiewicz, M.; Żółtowska, K. Variations in antioxidant defense during the development of the solitary bee Osmia bicornis. Apidologie 2015, 46, 432-444. [CrossRef]

24. Krishnan, N.; Kodrík, D.; Turanli, F.; Sehnal, F. Stage-specific distribution of oxidative radicals and antioxidant enzymes in the midgut of Leptinotarsa decemlineata. J. Insect Physiol. 2007, 53, 67-74. [CrossRef]

25. Urbańska, A. Occurrence and source of hydrogen peroxide in aphids. Electron. J. Pol. Agric. Univ. 2009, 12, 4. 
26. Cai, Q.-N.; Han, Y.; Cao, Y.-Z.; Hu, Y.; Zhao, X.; Bi, J.-L. Detoxification of gramine by the cereal aphid Sitobion avenae. J. Chem. Ecol. 2009, 35, 320-325. [CrossRef]

27. Board, P.G.; Menon, D. Glutathione transferases, regulators of cellular metabolism and physiology. Biochim. Biophys. Acta Gen. Subj. 2013, 1830, 3267-3288. [CrossRef]

28. Mehrabadi, M.; Bandani, A.R.; Kwon, O. Biochemical characterization of digestive $\alpha$-d-glucosidase and $\beta$-d-glucosidase from labial glands and midgut of wheat bug Eurygaster maura (Hemiptera: Scutelleridae). Entomol. Res. 2011, 41, 81-87. [CrossRef]

29. Dancewicz, K.; Paprocka, M.; Morkunas, I.; Gabryś, B. Struggle to survive: Aphid—plant relationships under low-light stress. A case of Acyrthosiphon pisum (Harris) and Pisum sativum L. Arthropod. Plant Interact. 2018, 12, 97-111. [CrossRef]

30. Urbanska, A.; Freddy Tjallingii, W.; Dixon, A.F.G.; Leszczynski, B. Phenol oxidising enzymes in the grain aphid's saliva. Entomol. Exp. Appl. 1998, 86, 197-203. [CrossRef]

31. Conti, B. Considerations on temperature, longevity and aging. Cell. Mol. Life Sci. 2008, 65, 1626-1630. [CrossRef] [PubMed]

32. Mołoń, M.; Dampc, J.; Kula-Maximenko, M.; Zebrowski, J.; Mołoń, A.; Dobler, R.; Durak, R.; Skoczowski, A. Effects of temperature on lifespan of Drosophila melanogaster from different genetic backgrounds: Links between metabolic rate and longevity. Insects 2020, 11, 470. [CrossRef]

33. Dampc, J.; Kula-Maximenko, M.; Molon, M.; Durak, R. Enzymatic defense response of apple aphid Aphis pomi to increased temperature. Insects 2020, 11, 436. [CrossRef] [PubMed]

34. Blackman, R.L.; Eastop, V.F. Aphids of the World's Plants: An Online Identification and Information Guide. Available online: http:/ / www.aphidsonworldsplants.info (accessed on 26 May 2021).

35. Gupta, R.; Tara, J.S. Life history of Aphis pomi De Geer (green apple aphid) on apple plantations in Jammu Province, J\&K, India. Munis Entomol. Zool. 2015, 10, 2-6.

36. Mehrparvar, M.; Mansouri, S.M.; Hatami, B. Some bioecological aspects of the rose aphid, Macrosiphum rosae (Hemiptera: Aphididae) and its natural enemies. Acta Univ. Sapientiae Agric. Environ. 2016, 8, 74-88. [CrossRef]

37. Wieczorek, K.; Światek, P.; Durak, R. Influence of selected biogenic amines on development and demographic parameters of a temperate population of Cinara (Cupressobium) cupressi (Hemiptera, Aphididae). Arthropod. Plant Interact. 2021, 1-11. [CrossRef]

38. Durak, R.; Borowiak-Sobkowiak, B.; Socha, M. Bionomy and ecology of Cinara cupressi (BUCKTON, 1881) (Hemiptera, Aphidoidea). Pol. J. Entomol. 2007, 2, 107-113.

39. Alford, D.V. Pests of Ornamental Trees, Shrubs and Flowers: A Colour Handbook, 2nd ed.; Manson Publishing: London, UK, 2012.

40. Bowler, K.; Terblanche, J.S. Insect thermal tolerance: What is the role of ontogeny, ageing and senescence? Biol. Rev. 2008, 83, 339-355. [CrossRef]

41. Kingsolver, J.G.; Arthur Woods, H.; Buckley, L.B.; Potter, K.A.; MacLean, H.J.; Higgins, J.K. Complex life cycles and the responses of insects to climate change. Integr. Comp. Biol. 2011, 51, 719-732. [CrossRef]

42. Durak, R.; Molon, M.; Durak, T.; Chrzanowski, G. The enzymatic markers of the adaptation of Cinara tujafilina to changing the host plant. Ethol. Ecol. Evol. 2018, 30, 416-429. [CrossRef]

43. Aebi, H. [13] Catalase in vitro. In Methods in Enzymology; Elsevier: Amsterdam, The Netherlands, 1984; Volume 105, pp. 121-126.

44. Katagiri, C. $\alpha$-D-Glucosidase in the serum of the american cockroach, Periplaneta americana. Insect Biochem. 1979, 9, 199-204. [CrossRef]

45. Leszczynski, B.; Dixon, A.F.G. Resistance of cereals to aphids: The interaction between hydroxamic acids and glutathione S-transferases in the grain aphid Sitobion avenae (F.) (Hom., Aphididae). J. Appl. Entomol. 1992, 113, 61-67. [CrossRef]

46. Miles, P.W. Studies on the salivary physiology of plant bugs: Oxidase activity in the salivary apparatus and saliva. J. Insect Physiol. 1964, 10, 121-129. [CrossRef]

47. Laurema, S.; Varis, A.-L.; Miettinen, H. Studies on enzymes in the salivary glands of Lygus rugulipennis (Hemiptera, miridae). Insect Biochem. 1985, 15, 211-224. [CrossRef]

48. Fehrmann, H.; Dimond, A.E. Peroxidase activity and Phytophthora resistance in different organs of the potato plant. Phytopathology $1969,57,69-72$.

49. Lowry, O.H.; Rosebrough, N.J.; Farr, A.L.; Randall, R.J. Protein measurement with Folin reagent. J. Biol. Chem. 1951, 193, 265-275. [CrossRef]

50. Enriquez, T.; Colinet, H. Basal tolerance to heat and cold exposure of the spotted wing drosophila, Drosophila suzukii. PeerJ 2017, 5, e3122. [CrossRef]

51. Ma, C.S.; Wang, L.; Zhang, W.; Rudolf, V.H.W. Resolving biological impacts of multiple heat waves: Interaction of hot and recovery days. Oikos 2018, 127, 622-633. [CrossRef]

52. Lu, Y.; Bai, Q.; Zheng, X.; Lu, Z. Expression and enzyme activity of catalase in Chilo suppressalis (Lepidoptera: Crambidae) is responsive to environmental stresses. J. Econ. Entomol. 2017, 110, 1803-1812. [CrossRef]

53. Farjan, M.; Dmitryjuk, M.; Lipiński, Z.; Biernat-Łopieńska, E.; Zółtowska, K. Supplementation of the honey bee diet with vitamin C: The effect on the antioxidative system of Apis mellifera carnica brood at different stages. J. Apic. Res. 2012, 51, 263-270. [CrossRef]

54. Williams, J.B.; Roberts, S.P.; Elekonich, M.M. Age and natural metabolically-intensive behavior affect oxidative stress and antioxidant mechanisms. Exp. Gerontol. 2008, 43, 538-549. [CrossRef] [PubMed]

55. Molon, M.; Zadrag-Tecza, R. Effect of temperature on replicative aging of the budding yeast Saccharomyces cerevisiae. Biogerontology 2016, 17, 347-357. [CrossRef] [PubMed] 
56. Van Voorhies, W.A.; Ward, S. Genetic and environmental conditions that increase longevity in Caenorhabditis elegans decrease metabolic rate. Proc. Natl. Acad. Sci. USA 1999, 96, 11399-11403. [CrossRef] [PubMed]

57. Borowiak-Sobkowiak, B.; Woźniak, A.; Bednarski, W.; Formela, M.; Samardakiewicz, S.; Morkunas, I. Brachycorynella asparagi (Mordv.) Induced-Oxidative stress and antioxidative defenses of Asparagus officinalis L. Int. J. Mol. Sci. 2016, 17, 1740. [CrossRef]

58. Durak, R.; Dampc, J.; Dampc, J. Role of temperature on the interaction between Japanese quince Chaenomeles japonica and herbivorous insect Aphis pomi (Hemiptera: Aphidoidea). Environ. Exp. Bot. 2020, 176, 104100. [CrossRef]

59. Durak, R.; Jedryczka, M.; Czajka, B.; Dampc, J.; Wielgusz, K.; Borowiak-Sobkowiak, B. Mild abiotic stress affects development and stimulates hormesis of hemp aphid Phorodon cannabis. Insects 2021, 12, 420. [CrossRef]

60. Durak, R.; Borowiak-Sobkowiak, B. Influence of temperature on the biological parameters of the anholocyclic species Cinara tujafilina (Hemiptera: Aphidoidea). Cent. Eur. J. Biol. 2013, 8, 570-577. [CrossRef]

61. Zhao, F.; Hoffmann, A.A.; Xing, K.; Ma, C. Life stages of an aphid living under similar thermal conditions differ in thermal performance. J. Insect Physiol. 2017, 99, 1-7. [CrossRef] 